\title{
China's Geostrategic Interests in the Indian Ocean Region: Implications for Kenya
}

\author{
Paul Odhiambo \\ Kenya Institute for Public Policy Research and Analysis, 2nd Floor Bishops \\ Garden Towers, Bishops Road, P.O. Box 56445-0020o, Nairobi, Kenya \\ podhiambo@kippra.or.ke
}

\begin{abstract}
China's growing influence in the Indian Ocean cannot be gainsaid as the East Asian economic powerhouse engages in a series of activities to secure maritime routes for energy supplies; to guarantee its trade routes; and to exercise increased maritime influence on the sea lines of communication (SLOCs). Since the beginning of the 21st century, Beijing has enhanced its presence in the Indian Ocean Region (IOR) through construction of ports, increased Chinese naval presence, participation in anti-piracy operations in the Gulf of Aden, construction of a military base in Djibouti, One belt One road initiative and 21st century Maritime Silk Road. While China reassures of its peaceful development, critics contend that Beijing's military-strategic intentions are aimed at dominance in the Indian Ocean. Countries of the IOR are a home to 2.5 billion people. About 8 o percent of the world's maritime oil trade flows through three chokepoints in the Indian Ocean. Moreover, Indian Ocean is emerging as a pivotal zone due to fast growing economies in the region. Due to its geostrategic significance, the Indian Ocean is expected to play a considerable role in the development of East African littoral states including Kenya. This paper analyzes the growing presence of China in IOR and how Nairobi's engagement with Beijing could enable Kenya to realize its geostrategic interests in the Indian Ocean. The paper recommends that Kenya needs to have effective strategies to maximize the potential from its exclusive economic zone and secure its national interests as a littoral state.
\end{abstract}

\section{Keywords}

Sea Lines of Communications - Strings of Pearls - littoral states - asymmetric relationship - go-out policy 
China's growing maritime presence in the Indian Ocean and Indian Ocean Region (IOR) has been significant in the last decade. Beijing has expanded its footprint in the Indian Ocean through development of maritime infrastructure in littoral states (String of Pearls); increase of robust diplomatic and trade relations with IOR countries; launching of the 21st century Maritime Silk Road in 2013; engagement in anti-piracy operations in the Gulf of Aden in 2008; establishment of a naval base in Djibouti and intensification of Chinese naval power projection in the IOR. The changing economic conditions of China and 'open up' policy initiated by Deng Xiaoping in 1978 and reformation of the People's Liberation Army Navy (PLAN) under Liu Huaqing in the 1980s played a crucial role in the recognition of the strategic position of Pacific Ocean in safeguarding China's maritime interests (Sun and Bayette, 2017). As a result, the PLAN had to adapt to changing conditions in which its role and zone of operations would be expanded as China would be entering into new economic and geopolitical realities.

The 'Open Door Policy' marked the turning point in the history of the economic development of China as the country opened for foreign investment (Zakic and Radisic, 2017). Xiaoping's intention was to spread business of Chinese enterprises overseas. In 1999, the leadership of President Jiang Zemin, Go-Out Policy (the Going Global Strategy) was initiated to promote Chinese investments abroad. However, the policy became effective after Beijing's entry into the World Trade Organization (WTO) in 2001. At first, China permitted state-owned corporations to invest abroad. In 2003, Chinese private companies were also permitted to invest overseas. China's integration into the global economy and overseas investment have shaped Beijing's foreign policies especially with regards to international maritime trade routes, energy security, international markets and protection of Chinese citizens and enterprises abroad.

Since defense was one of the Xiaoping's Four Modernizations (other three include agriculture, industry, and science and technology), reform of the People's Liberation Army (PLA) was necessary hence was initiated in early 1980s (Mason, 1984). General Liu Huaqing, who was the third commander of the PLAN between 1982 and 1988, played a considerable role in the Chinese defense reforms. He envisioned a three-step process by which Beijing would have a navy of global reach by second half of the 21st century. The first stage (20002010) involved China developing a naval force that could operate up to the first island chain. This step also included personnel and formation training, renovation and upgrading of ships. During the second stage (2010-202O), PLAN would become a regional force capable of projecting force to the second island chain. 
This stage consists in improving the combat capabilities of Chinese navy in the near seas by constructing light aircraft carriers and buying additional carrier fleets. On the other hand, at the third stage China would possess a blue-water navy with aircraft carriers as its centerpiece.

General Huaqing was majorly influenced by the American naval officer and historian Alfred Thayer Mahan. Mahan's core tenets about naval power were anchored on the control of seas which he viewed as imperative since they acted as maritime 'highway' for commerce and were a common resource for all states. Likewise, the control of seas in the contemporary world politics is critical for global and regional powers in expanding their power and wealth by using trade routes during peacetime and exploiting the seas for military objectives during times of war. Therefore, China's two ocean (Pacific and Indian) strategy can be explained and understood from the country's development trajectory; the need to secure trade routes and sLOcs; projection of maritime power to address regional and international threats; and the need to exploit energy reserves and natural resources that lie in the littoral states of the IOR (Suri, 2017).

\section{Significance of the Indian Ocean Region}

Indian Ocean is the third largest ocean in the world, covering a total area of 73.44 million $\mathrm{km}^{2}$. It accounts for about 20 percent of the total ocean area in the world. The Indian Ocean is bordered by India, Pakistan and Iran in the north; to the west is the Arab Peninsula and Africa; to the east is Australia, Indonesia and the Malay Peninsula; and to the south by the Southern Ocean ( $\mathrm{Li}, 2017)$. The Indian Ocean's uniqueness and importance can be derived from its several access points (Suri, 2017). The control of these access points put an influential country over the ocean to control extensive shipping lanes that transport critical cargo across the Indian Ocean. Therefore, the Indian Ocean has been described as the strategic crossroads of the Pacific Ocean, the Atlantic Ocean and the Mediterranean Sea (Li, 2017).

Indian Ocean has become a strategic hot spot in recent years as Asiatic emerging powerhouses focus on the expanse ocean due its international shipping lanes, vast energy reserves in littoral states, fisheries resources and fastgrowing economies in the IOR (Suri, 2017). Indian Ocean is imperative for global trade as it provides critical sea trade routes that connect the Middle East, Africa, South Asia and other regions. Several the world's most important and strategic chokepoints such as the Straits of Hormuz, Bab-el-Mandeb and Malacca through which an estimated 32.2 million of barrels of oil and 
petroleum are transported per day are found in the IOR. It is estimated that the sea routes in the Indian Ocean carry two-thirds of the world's seaborne trade in oil; $5^{\circ}$ percent of the seaborne container traffic and a third of the world's seaborne bulk cargo.

The IOR is a home to about 2.5 billion people, with some of the fast-growing economies in the world endowed with abundant and diverse arable land, significant human resources and technological capacities. Indian Ocean is also rich in natural resources including 40 percent of the world's off oil production; fisheries account for 15 percent of the world's total and has increased 13-old between $195^{\circ}$ and 2010; rich in strategic and precious mineral resources including nickel, zinc, cobalt, iron, silver and gold. The IOR has also remained an important focal point in world affairs due to prevailing security threats from piracy, terrorism and armed conflicts amongst some littoral and non-littoral states (Rooyen, 2011).

The broad objective of this paper is to assess China's geostrategic interests in the IOR. The paper has three specific objectives namely; analysis of implications of String of Pearls and the "Belt and Road Initiative" to China's interests in the IOR; assessment of China's growing diplomatic ties and military capacities in the IOR; and assessment of how Kenya-China bilateral relationship could enable Nairobi to realize its geostrategic interests in the IOR.

\section{3} Theoretical Framework

The paper is underpinned by Randall Schweller's theories of rising great powers and Brantly Womack's asymmetry and international relationships. Schweller contends that the significant consequence of the rise of new great powers is international political change. By altering the configuration of power distribution in the international system, an emerging global power presents both opportunities and threats to established powers. Currently, the power shift in the international system due to rise of China (and to some extent India) is being seen as offering both opportunities and threats to the traditional western powers. States' responses to rising power(s) including preventive war, balancing, bandwagoning, binding, engagement and distancing/buckpassing. According to Schweller (1999), the choice of response(s) depends on the goal of the established powers.

Robert Gilpin and Jack Levy argue that statesmen of established powers are more attracted to preventive war/action to reverse or retard the rising military power of the perceived adversary. On the other hand, Organski and Jacek Kugler contend that it is the rising dissatisfied powers that initiate preventive 
war or action. Balancing refers to opposing the stronger or more threatening side in a conflict. Balancing strategy is achieved through internal balancing (mobilization of national resources to march those of the adversary) and external balancing (formation of alliance to challenge the rising state/coalition).

Traditionally, bandwagoning refers to joining the stronger coalition. For instance, states join powerful revolutionary power(s) to share the rewards of 'victory.' The rising revolutionary power(s) employ early spoils of their 'victories' or the promise of future gains to bring more states on their side. Binding refers to situation in which a state allies with the rival in order to manage the threat by means of a pact of restraint. The state that intends to bind the 'rival' state hopes to exert some measure of control over its policies so that it neutralizes the source of threat. Similarly, a multilateral binding policy is employed. In this cooperative approach, a rising power is incorporated in existing institutional arrangements so that its interests and concerns are accommodated. Through multilateral framework, the rising power is entangled in a web of policies that make exercise of its power outside the framework too costly.

Engagement refers to the use of non-coercive means to ameliorate the nonstatus quo elements of a rising major power's behavior so that the power and influence of the rising major power is used in a manner that does not undermine the existing regional and global order. The goal of engagement is to minimize conflict and avoid war without compromising the existing international order. Appeasement is a common form of engagement in which international grievances is resolved through negotiation and compromise. Buckpassing refers to a situation in which a state attempts to ride 'free' on the balancing efforts of other states. On the other hand, policy of distancing involves hiding by a state faced with threatened rising power. The hiding tactic is often employed when a state realizes that allying with other threatened states is not enough to deter or defeat the aggressor(s).

Brantly Womack (2016) contends that most international relationships between nation-states are asymmetric. The basic unit of analysis of asymmetric theory is the bilateral relationship between a dominant state and a smaller state. The object of attention in asymmetric theory is power differences in relationships. Asymmetry theory attempts to address the interaction of power and vulnerability between a dominant state and smaller state. Ordinarily, the relationship between a smaller state and a dominant state can be normal if the former does not feel threatened and the latter can assume that its capabilities are respected. While the smaller state normally has no capability of threatening the dominant state, the latter might not force its preferences on the smaller side at a cost acceptable to itself. This means that the dominant state is not 'omnipotent' while the smaller state is not 'impotent.' 
Womack further notes that in asymmetric relationship perspectives diverge. Capabilities of a state determines its perspective towards external engagement. While the smaller state has more stake and is more concerned how the relationship might change, the dominant state has proportionally less at stake in the relationship. As a result, the smaller state is concerned about its vulnerability to the dominant state hence requires assurance that its autonomy will be respected and safeguarded. A symmetry of power tends to lead to asymmetry of commitment in the sense that the smaller state is more inclined to resist sources of its vulnerability than the dominant state has interest to dominate. A country that is dominated in trade and investment is more likely to devote its attention to the skewed relationship than the dominant state that is likely to pay little attention to its international economic (trade and investment) relations as it is often preoccupied more with 'other' vital interests. It has been observed that economic disparity generates disparity of attention that favours the smaller state. Hence, the smaller state is likely to pursue policies to 'escape' from the domination.

Schweller's theories of rising powers and Womack's theory of asymmetric international relationships are imperative in explaining and understanding bilateral relationship between Kenya and China in the context of the latter's increasing presence and influence in the IOR. As a littoral state of the Indian Ocean, Kenya can benefit not only from the vast resources in its Exclusive Economic Zone but also from geostrategic location. In its bilateral relationship with the Asian powerhouse, Kenya could employ pragmatic strategies including bandwagoning and engagement to benefit from its maritime domain and its geostrategic location as a littoral state of the Indian Ocean. In cognizance of asymmetric power between Nairobi and Beijing, Kenya could safeguard its geostrategic interests in the IOR from the strength of disparity of attention. This means that more attention and vigilance should be the hallmark of Kenyan foreign policy posture with regards to bilateral agreements and Memorandum of Understanding (MoU) signed between Nairobi and Beijing. Clear core national interests and commitment of the common good should shape and guide Kenya's engagement with China to guarantee Nairobi's geostrategic interests in the IOR.

China's Increasing Influence in Indian Ocean Region

\section{1} The String of Pearls

China's strategic interests in the Indian Ocean have been largely driven by Beijing's desire to protect its sea lines of communication (SLOCs) that is critical for its energy security and international trade (Brewster, 2014). China's 
investment in Africa and reliance on energy supplies from Middle East and Africa have made the sLOcs through the IOR extremely crucial for Beijing (Suri, 2016). China's strategies to minimize its vulnerability in the Indian Ocean include deepening economic and political cooperation with Indian Ocean states; and building capacity to project limited naval and air power in the Indian Ocean among others. The String of Pearls entails China's increased levels of influence along sea routes through investment, port development and diplomatic engagement with the littoral states. The String of Pearls is also a strategy to expand Chinese naval presence in the IOR.

Since the term "String of Pearls" was coined more than fifteen years ago, there is little evidence to show that China could use ports along the Indian Ocean littoral as naval bases (Marantidou, 2014). The ports do not have structures and resources to support their establishment as traditional naval bases. However, they could be useful logistics support for the Chinese naval forces. Key port facilities in South Asia that form part of the String of Pearls include development of deep-sea port at Gwadar, Pakistan; construction of Hambantota port in Sri Lanka; modernization of the deep-sea port in Chittagong in Bangladesh; and Kyaukphyu port in Rakhine state, Myanmar. The school of thought that views China's intentions along the Indian Ocean littoral contend that assistance in the ports' development is a step towards establishing a blue-water navy for Beijing's power projection and protection of China's economic and national interests across the globe.

\subsection{The Belt and Road Initiative}

Launched in 2013 as the "One Road, One Belt," the foreign policy signature of Chinese President Xi Jinping, is now known as "the Belt and Road Initiative" since 2017. The Belt and Road Initiative comprises an overland "Silk Road Economic Belt" and an over-water "Maritime Silk Road." The overland infrastructure consists of a series of proposed networks linking Central Asia to South Asia, the Middle East and onwards to Africa and Europe. On the other hand, the overwater infrastructure envisions shipping routes through the South China Sea and the Indian Ocean towards South Asia, the Middle East, Africa and Europe (Scobell et al., 2018). Essentially, the Silk Road Economic Belt refers to three routes namely the Northern route-Beijing-Russia-Germany-Northern Europe; the middle route - BeijingXi'an-Urumqi-Afghanistan-Kazakhstan-Hungary-Paris; and the Southern route - Beijing-Southern Xinjiang-Pakistan-Iran-Iraq-Turkey-Italy-Spain. The Maritime Silk Road (MSR) connects China's coastal cities with the Pacific and Indian oceans and extends to the South China Sea, Strait of Malacca, Bay of Bengal, Arabian Sea, Gulf of Aden and Persian Gulf. Countries in the MSR include ASEAN, South Asia, West Asia and Africa. 
The Belt and Road Initiative (BRI) is expected to become a trans-regional cooperation model linking Asia, Africa and Europe's policies, trade, facilities, funds and people in the 21st century (Wang, 2016). The overall objective of the BRI is to promote orderly and free flow of economic factors, efficient allocation of resources and intensified regional integration of markets to provide impetus for the coordination of economic policies of countries along the route so as to establish an economic cooperation framework that is inclusive, open, balanced and beneficial for all states involved. From Beijing's perspective, the BRI will enable China to transfer its advantages in productivity, technology, funding, experience and development into cooperation opportunities to the rest of the world. Secondly, the BRI intends to realize global rebalancing by advocating for inclusive development in the international system and encouraging opening of the West to promote development of China's western regions and inland areas such as Central Asian countries and Mongolia. Thirdly, the BRI emphasizes wide consultation, joint contribution and shared benefits in the interests of international community.

The opportunities of the BRI include the establishment of an open cooperation platform that will serve the common interests of participating countries along the routes. The BRI is also seen as critical in bringing the benefits of the Chinese development model and Chinese benefits across the world. China's technology and infrastructure development through the BRI are likely to benefit countries along the Belt and Road as Beijing has advantages in areas such as high-speed trains, nuclear power, high-end equipment, construction materials and production lines. The BRI is also expected to enhance connectivity of the world especially the countries that will be part of the Initiative. In addition, the BRI advocates for a community of common destiny in which no country seeks dominance. Through вRI, China aspires for regional economic integration that explores similarities and common interests rather than hegemony.

In the past two decades, China has deepened its economic and political cooperation with South Asian countries, Southeast Asia countries and other littoral states of the Indian and Pacific oceans. Beijing's influence in South Asia has increased through deepening of economic and political relationships with Nepal, Bangladesh, Sri Lanka and Maldives (Brewster, 2014). Beijing has employed both strategic and economic support to regional countries. South Asian navies do procure Chinese naval assets and are often engaged in joint development 
of combat ships and submarines. China has also invested heavily in maritime infrastructure especially deep-water ports in the region. Beijing is Sri Lanka's major source of infrastructure investment including the Hambantota Port. China also considers Myanmar as an attractive strategic partner in the region.

\section{China's Growing Military Capabilities in IOR}

Since the beginning of the 21st century, Chinese navy has been expanding its presence in the Indian Ocean. In 2000, the PLAN made its first visit to the western Indian Ocean with calls in Tanzania and South Africa. China has considerably increased its naval presence in the Indian Ocean since it began engaging in anti-piracy operations in the Gulf of Aden in 2008. The continued participation of the Chinese navy in the anti-piracy operations long after most pirate attacks ended has demonstrated China's commitment to protect its national interests and project naval power in the Indian Ocean. Chinese personnel engaged in anti-piracy campaigns in the Gulf of Aden have made several ports' calls in Algeria, Bahrain, Djibouti, Egypt, India, Kenya, Kuwait, Morocco, Mozambique, Oman, Qatar, Seychelles, Saudi Arabia, Sri Lanka, Tanzania, United Arab Emirates and Yemen.

In 2004, President Hu Jintao called for PLA's four "New Historic Missions" including; ensuring military continued support for Chinese Communist Party (ССP) rule in China; defending China's sovereignty, territorial integrity and national security; protection of China's expanding national interests; and helping to ensure a peaceful global environment and promotion of mutual development (Yung et al., 2014). The third mission has given the Chinese military new responsibilities to help in protecting China's overseas economic, political and security interests. Between 2003 and 2014, China's foreign trade increased from US $\$ 851$ billion to US $\$ 4.16$ trillion. During this period, Beijing became a major exporter to countries in the global North and South. China also became the largest oil importer in 2013. China's increasing importation of oil, natural gas, minerals and other resources from the Middle East, Africa, Latin America and the rest of the world meant that Beijing would be dependent on maritime trade routes in the Persian Gulf, Indian Ocean, South China and the Strait of Malacca among others. Similarly, Chinese foreign direct investment abroad has increased in the past two decades. Therefore, protection of Chinese citizens overseas, protection of Chinese property and assets, protection of Chinese shipping and sea lines of communication have become foreign policy and national security priority. 
The 2015 China's Military Strategy recognizes a shift from Offshore Water Defense to a combination of Offshore Water Defense and Open Seas Protection. The Strategy acknowledges the great importance of seas and oceans in the protection of the country's maritime rights and interests. The quest to develop a modern maritime military force structure is driven by the country's national interests and development interests; desire to safeguard the country's national sovereignty and maritime rights and interests; protection of SLOC s and overseas interests and the need to participate in international maritime cooperation. China's Defense White Paper 2019 also recognizes overseas interests as critical part of the country's national interests. One of the key missions of the Chinese armed forces is to effectively protect the security and legitimate rights and interests of overseas Chinese people, organizations and institutions (Defence White Paper, 2019). To overcome its challenges, Chinese navy intends to build far seas forces, develop overseas logistical facilities and enhance capabilities in achieving multi-military tasks.

The establishment of a military base in Djibouti has been a major step towards China realizing its global naval reach. While Beijing insists that the Djibouti 'support facilities' will be used largely for logistical support and recuperation of Chinese personnel involved in multilateral peace support operations or humanitarian rescue activities, critics contend that the Djibouti military base will give China experience to build more overseas military bases (Chaziza, 2018). The choice of Djibouti for the China's first military base is anchored on the country's geo-political and geo-economic location. Djibouti is located at one of the busiest shipping lanes in the world. Moreover, Djibouti is at a critical junction that links the Middle East, Europe, Far East and the Horn of Africa.

\section{China in IOR: Implications for Kenya's Geostrategic Interests}

China's growing influence in the IOR in the past two decades cannot be gainsaid. However, it is important to note that India's and United States' influence and presence in the Indian Ocean is still enormous. Aware of its limits in the Indian Ocean, Beijing has developed a mixture of strategies and policies including diplomacy, maritime cooperation with littoral states and enhancing its naval capabilities to mitigate its vulnerability and geopolitical risks in the IOR (Yung, 2014). China's strategies, policies and actions in the Indian Ocean and the wider IOR have implications for littoral states' geostrategic interests. As a littoral state, Kenya has the potential to realize its geostrategic interests 
through effective strategies, policies and engagement with extra-regional powers with massive influence and interests in the IOR.

Kenya has a maritime territory of $230,000 \mathrm{~km}^{2}$ and 200 nautical miles offshore. The oceanic territory is believed to have vast resources that have potential for spurring economic growth, poverty reduction and achievement of sustainable development (Muigua, 2018). Kenya has huge potential in marine fisheries, offshore hydrocarbon resources reserves, tourism, forestry, shipping and deep-sea mining among others. However, there are challenges that have undermined the harnessing the blue economy potential and Kenya's geostrategic interests in the Indian Ocean. The challenges experienced at Kenya's maritime territory include illegal and unregulated fishing; piracy and armed robbery; illicit trade in contraband goods; human and drug trafficking; degradation of marine ecosystems through discharge of oil and toxic waste, illegal sand harvesting, and destruction of coral reefs and coastal forests.

Kenya's key geostrategic interests in the Indian Ocean include security of the maritime international trade routes, potential oil and gas reserves in the Lamu basin, marine fisheries resources and tourism. As the gateway for regional countries, the safety of the maritime trade routes is crucial for Kenya's interests in the Indian Ocean. Piracy and maritime terrorism, transnational criminal syndicates in the ocean comprise the maritime trade routes. Therefore, the role of Kenya's instruments of diplomacy and security institutions is critical in guaranteeing security and safety of maritime trade routes.

On the other hand, the efficiency and effective maintenance of transport infrastructure including ports, railway lines, pipelines and related facilities are imperative in achieving Kenya's geostrategic interests. The maritime dispute between Kenya and Somalia is increasingly becoming a hurdle to the latter's offshore oil and gas exploration in the Lamu basin. A lasting solution of the maritime row will be critical for extension of Kenya's Exclusive Economic Zone, development of the Blue Economy especially exploration of the hydrocarbon resources and other minerals, fisheries development in Lamu County and the viability of the new Lamu Port under construction. Coastal tourism still plays a considerable role for the country's tourism performance hence the maintenance of beaches, security and adequate tourism services are likely to enhance Kenya's tourism sector.

Kenya is the centre of gravity in East Africa at it serves as the centre for the region's trade, business, logistics hub, diplomacy and security efforts. Major and middle extra-regional powers enter the region through Kenya. Kenya is the largest economy in East and Central Africa and the third largest economy in Sub-Saharan Africa. With advanced human capital, diversified economy, 
a leader in information and communication technology in the region and a strong private sector, Kenya's economy plays a considerable role in the economic performance of regional economies.

Kenya-China bilateral relations date back to independence in 1963 when Kenya became a sovereign state. Over the years, the two countries have deepened their bilateral relationship especially in trade, investment, infrastructure development, technical cooperation, education, agriculture, energy, education and cultural exchange, security among others. China has become a major trading partner of Kenya due to enhanced bilateral cooperation between the two countries in the past decade. Beijing became the leading source of imports for Kenya in 2015. Chinese's imports into Kenya has considerable increased in the last ten years as shown in Fig. 1 below. For instance, China's imports grew from Ksh 120.6 billion in 2010 to Ksh 376.7 billion in 2019. On the hand, Kenya's exports to China has increased marginally. While Kenya's exports to China in 2010 was valued at Ksh. 2.5 billion, it rose to Ksh 15.1 billion in 2019. The bilateral cooperation in other issue area has also deepened in the last fifteen (15) years.

Kenya needs to engage the East Asian powerhouse more effective on areas of mutual interests with regards to the Indian Ocean. Partnership on safeguarding maritime security could be critical in enhancing maritime shipping lines. Building capacity for the Kenya Navy, Coast Guard Service and other security personnel. Bilateral cooperation in marine fisheries development could be crucial in increasing the output from Kenya's Indian Ocean waters. While freshwater fish accounted for Ksh 19.4 billion in 2018, marine fish performance

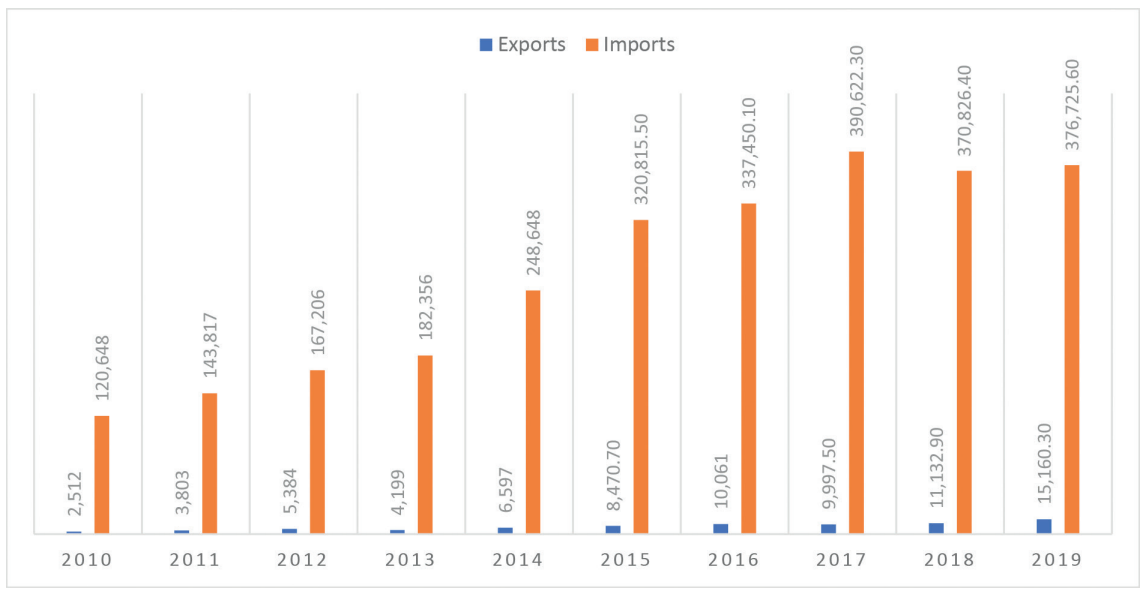

FIGURE 1 Kenya-China trade relations, exports and imports, Ksh million SOURCE: KNBS ECONOMIC SURVEY (VARIOUS EDITIONS) 
was only Ksh 4.4 billion. The low share of marine fish is attributed to lack of technology and inadequate facilities critical for deep-sea fishing (Economic Survey, 2019).

\section{$8 \quad$ Conclusion}

China's growing presence in the Indian Ocean is expected to have ramification for both littoral states and extra-regional powers like the United States. Due to increased bilateral cooperation between China and littoral states, the two sides could find a common ground of enhancing their geostrategic interests in the Indian Ocean. As a littoral state, Kenya stands to gain by deepening its engagement with China in areas of mutual interests in the Indian Ocean. Key areas that should be given priority are security and safety of Kenya's maritime waters to protect maritime trade routes, development of fisheries and offshore exploration and mining of resources in deep ocean bed, collaboration in tourism sector and development and maintenance of transport, port and related infrastructure to ensure that Kenya's geostrategic position as the gateway of East and Central Africa is guaranteed.

\section{References}

Brewster, D. (2014). Beyond the "String of Pearls": Is there really a Sino-Indian Security Dilemma in the Indian Ocean? Journal of the Indian Ocean Region, 10(2), 133-149. do i: $10.1080 / 19480881.2014 .922350$

Chaziza, M. (2018). China's Military Base in Djibouti. Middle East Security and Policy Studies No. 153. Retrieved from https://besacenter.org/wp-content/uploads/2018/ o8/153-Chaziza-Chinas-Military-Base-in-Djibouti-web.pdf.

Cooper, Z. (2018). Security implications of China's military presence in the Indian Ocean. csis Briefs, March 2018. Retrieved from https://csis-website-prod.s3.amazon aws.com/s3fs-public/publication/180627_Cooper_SecurityImplications.pdf?BC9DJ Q8a4bZDRcAWYou2qR5..7EwzZ9G.

Ghedi, A. J. (2012). China geostrategic and resources interests in the Horn of Africa: Somalia-Kenya limits of the continental shelf and implications. In J. Shikwati (Ed.), China-Africa Partnership: The Quest for Win-Win Relations. Inter Region Economic Network.

Fatima, Q. \& Asma, J. (2015). The political and economic significance of Indian Ocean: An analysis. A Research Journal of South Asian Studies, 30(2), 73-89. 
Hatcher, J. (2013). China's Growing Indian Ocean Maritime Interests: Sowing the Seed of Conflict? Soundings No. 2. Sea Power Centre - Australia.

Holmes, J. R., \& Yoshihara, T. (2008). China and the United States in the Indian Ocean: An emerging strategic triangle? Naval War College Review, 6r(3), Article 4.

Li, J. (2017). Developing China's Indian Ocean strategy: Rationale and prospects. China Quarterly of International Strategic Studies, 3(4), 481-497. doi:10.1142/ S2377740017500270.

Njiru, J. M., Ruwa, R. K., Kimani, E. N., Ong’anda, H. O., Okemwa, G. M., \& Osore, M. K. (Eds.) (2018). The RV Mtafiti: Marine Research Towards Food Security and Economic Development in Kenya. Kenya Marine and Fisheries Research Institute (KMFRI).

Mbugua, J. K., \& Mwachinalo, M. S. (2017). An sssessment of maritime insecurity in the Kenyan domain. Occasional Paper, Series 8, No. 1. IPSTC Peace and Security Research Department.

Melvin, N. (2019). The new external security politics of the Horn of Africa. SIPRI Insights on Peace and Security. No. 2019/2, April 2019.

Michel, D., \& Sticklor, R. (Eds.) (2012). Indian Ocean rising: Maritime security and policy challenges. Stimson.

Muigua, K. (2019). Harnessing the blue economy: Challenges and opportunities for Kenya. Essay.

Mumuni, S. M., \& Murphy, S. M. (2018). China's "going global" policy in Africa: An exploratory overview of an evolving policy framework. Journal of Asian Research, 2(1).

Netherlands Institute of International Relations. (2018). China and the EU in the Horn of Africa: Competition and Cooperation? Retrieved from https://www.clingendael. org/publication/china-and-eu-horn-africa.

Pathak, V. (2009). China and Francophone Western Indian Ocean region: Implications for Indian interests. Journal of Defence Studies, 3(4), 79-102.

Qi, X., Erickson, A. S., \& Goldstein, L. J. (2006). Maritime geostrategy and the development of the Chinese navy in the early twenty-first century. Naval War College Review, 59(4), 46-67.

Republic of Kenya. (2019). Twelfth Parliament - Third Session. The National Assembly, Votes and Proceedings, August 7, 2019.

Rustomjee, C. (2018). Green shoots for the African blue economy? Policy Brief No. 132. Centre for International Governance Innovation (CIGI).

Scobell, A., Lin, B., Shatz, H. J., Johnson, M., Hanauer, L., Chase, M. S., Stuth Cevallos, A., Rasmussen, I. W., Chan, A., Strong, A., Warner, E. \& Ma, L. (2006). At the Dawn of Belt and Road: China in the Developing World. RAND Corporation. Retrieved from https://www.rand.org/pubs/research_reports/RR2273.html.

Ruwa, R. (2006). Coastal and offshore marine fisheries of Kenya: Status and opportunities. Retrieved from https://www.oceandocs.org/bitstream/handle/1834/ 7096/ktfo124.pdf?sequence=1. 
Sokinda, S. (2015). India's strategy for countering China's increased influence in the Indian Ocean. The Centre for Defence and Strategic Studies (CDSs).

Schweller, R. (1999). Managing the Rise of Great Powers: History and Theory. Routledge. Sun, T. \& Payette, A. (2017). China's two ocean strategy: Controlling waterways and the New Silk Road. Asia Focus \#31. IR Is.

Suri, G. (2017). China's expanding military maritime footprints in the Indian Ocean region (IOR): India's response. Vivekananda International Foundation. Pentagon Press.

Tovy, T. (2015). The Changing Nature of Geostrategy 1900-2000: The Evolution of A New Paradigm. Air University Press

UNDP. (2018). Leveraging the blue economy for inclusive and sustainable growth. Policy Brief Issue No: 6/2018.

United Nations Economic Commission for Africa. (2016). Africa's blue economy: A policy handbook. Policy Report. Economic Commission for Africa.

Wang, Y. (2016). The Belt and Road Initiative: What Will China Offer the World in its Rise. New World Press.

Ward, J. D. (2017). The emerging geopolitics of the Indian Ocean region. Asia Pacific Bulletin, 386 .

Wendt, J. (2000). The Select Methods of Investigations in Geostrategy and Geopolitics. Political Studies in Central and Eastern Europe. Retrieved from https://www.oceandocs.org/bitstream/handle/1834/7096/ktfo124.pdf?sequence=1.

Yung, C. D. \& Rustici, R. (2014). "Not an idea we have to shun": Chinese overseas basing requirements in the 21st century. China Strategic Perspectives, No. 7. National Defense University Press. Retrieved from https://ndupress.ndu.edu/Portals/68/ Documents/stratperspective/china/ChinaPerspectives-7.pdf. 